April 7, 2013

\title{
Credit Ratings and the Pricing of Sovereign Debt during the Euro Crisis
}

\author{
Joshua Aizenman, Mahir Binici, and Michael Hutchison*
}

April 2013

\begin{abstract}
This paper identifies the impact of credit rating changes on the sovereign spreads in Europe and investigates the macro and financial factors that account for the time varying effects of a given credit rating change. We find that changes of ratings are informative, significant economically, and robust even after controlling for conventional fundamentals. A one unit rise in the average credit rating (in a scale index of 25 ratings) decreases CDS spreads by about 45 basis points, on average. However, the association between credit rating changes and spreads follows a complicated non-linear pattern dependent on the level of the credit rating. Applying a non-linear "spline" regression, we find high sensitivity (large change in spreads for a given change in ratings) at the very low end of credit ratings and then a $U$ shape pattern-- ratings at the moderately low end (B-) and very high end of credit levels (above A) are fairly insensitive, while middle ratings are quite sensitive to credit rating changes (with the highest sensitivity at the BB+ level). We also find that European countries had quite similar CDS responses to credit rating changes during the pre-crisis period, but that large differences emerged between the now highlysensitive GIIPS group and other European country groupings (EU and Euro Area excluding GIIPS, and the non-EU area). We also find that contagion from changing the ranking of the GIIPS on other euro countries disappears when own-country credit rating changes are taken into account. In contrast, a decline in the credit rating in the GIIPS area is transmitted as a decline in the CDS spread of Non-Euro EU, which may be deemed as a substitute asset that increases in demand when the perceived risk of GIIPS sovereign debt increases.
\end{abstract}

Key words: CDS Spreads, Credit Ratings, Sovereign Debt, Eurozone

JEL Classification: F30, G01, G24, H63

\footnotetext{
*USC and the NBER [aizenman@usc.edu]; Central Bank of Turkey [mahir.binici@tcmb.gov.tr]; and UCSC [hutch@ucsc.edu], respectively.
} 


\section{Introduction and Overview}

Concerns about the information content of credit ratings and their association with sovereign spreads and default risk were mostly muted during the Great Moderation period. The global crisis of 2008-9, and especially the on-going Euro crisis, again put to the fore these issues at the time of an unprecedented rise in volatility. The purpose of our study is to investigate how changes in credit ratings and economic factors have influenced CDS spreads in Europe in the context of the recent crises. Specifically, we use monthly data, January 2005 to August 2012, for 27 European countries, to evaluate the transmission of credit rating changes on sovereign spreads of a given country, while controlling for country-specific and global economic factors. We also investigate cross-border transmission of credit rating changes, and the degree to which these associations are time dependant and nonlinear. The focus on Europe allows us to investigate the oft-expressed concern the market pricing of sovereign risk during the crisis may not be justified by economic fundamentals, and whether the association between credit ratings the pricing of sovereign debt is influenced by participation in the Euro Zone or EU. In addition, contrasting the crisis period (and heighted volatility of shocks) with the preceding period of relative market tranquillity provides sharper identification of these linkages.

We find that changes in credit ratings are informative, significant economically, and robust, even after controlling for conventional economic fundamentals. Specifically, a one unit rise in the average credit rating (in a scale index of 25 ratings) decreases CDS spreads by about 45 basis points, while a one percent rise in the domestic stock price index lowers CDS spreads by 1.5 to 2.0 basis points. World commodity and oil price increases also consistently decrease CDS spreads, likely because world economic conditions are generally strong when these prices are rising. By contrast, a rise in global market uncertainty, proxied by the VIX index, increases domestic CDS spreads. These effects are sizable: a one standard deviation rise in credit ratings lowers CDS spreads by 0.15 of a standard deviation, similar to the effect of a one standard deviation rise in equity prices. However, standardized changes in commodity prices, oil prices or the VIX, have smaller effects on CDS spreads. The main result is robust and persistent: credit rating changes have important statistical and economic effects on CDS spreads, even when controlling for a host of domestic and economic variables. 
As the credit rating scale does not correspond in any rigid way to fundamentals, there is no prior reason to expect it to be linked in a linear manner to actual sovereign spreads. Indeed, we find that the association between credit rating changes and spreads follows a complicated nonlinear pattern dependent on the level of the credit rating. Applying a non-linear "spline" regression, we find high sensitivity (large change in spreads for a given change in ratings) at the very low end of credit ratings and then a $U$ shape - ratings at the moderately low end (B-) and very high end of credit levels (above A) are fairly insensitive, while middle ratings are quite sensitive to credit rating changes (with the highest sensitivity at the $\mathrm{BB}+$ level). We also find that European countries had quite similar CDS responses to credit rating changes during the pre-crisis

period, but that large differences emerged during the crisis period between the now highlysensitive GIIPS group and other European country groupings (EU and Euro Area excluding GIIPS, and the non-EU area). Clearly, the response is largest in magnitude at the lowest credit rating but these effects appear to emerge mainly during the crisis period when the risk of sovereign default rises and markets price risk more aggressively.

The contagion from changing the ranking of the GIIPS on other euro countries disappears when own-country credit rating changes are taken into account. By contrast, the GIIPS credit rating changes have a positive effect on the non-Euro EU: a rise decline in the credit rating in the GIIPS area is transmitted as a decline in the CDS spread of Non-Euro EU. This is consistent with the Non-Euro EU area sovereign debt deemed as a substitute asset that increases in demand when the perceived risk of holding GIIPS area sovereign debt increases.

We start with a brief overview of the background literature and the data, continue with the empirical analysis, and close with concluding remarks.

\section{Literature Review}

The debate about the role and functioning of the credit rating agencies pre-dates the global crisis of 2008-9 and its aftermath. Cantor and Packer (1994) pointed out that although the ratings provide accurate rank-orderings of default risk, the meaning of specific letter grades varies over time and across agencies. Noting that current regulations do not explicitly adjust for agency differences, the authors argue that a reassessment of the use of ratings and the adequacy of public oversight is overdue. In their follow up paper, Cantor and Packer (1997) noted that regulations incorporate private sector credit ratings to determine investment prohibitions and capital 
requirements for institutional portfolio investments. These regulations implicitly assume that different agencies have equivalent rating scales, despite the fact that some agencies assign systematically higher ratings than others. They tested whether observed rating differences reflect different rating scales or simply result from sample selection bias, and found only limited evidence of selection bias.

Partnoy (1999) outlined a critical view of the role credit rating agencies in providing information about bonds. The "reputational capital" view of credit rating agencies has been that the agencies have survived and prospered since the early 1900s based on their ability to accumulate and retain good reputations by providing valuable information about the bonds they rate. Partnoy argued that this view fails to explain, and is inconsistent with the estimation of credit spreads, the number of credit ratings-driven transactions, and the explosion in use of credit derivatives. In place of the reputational capital view, he offers a "regulatory license" view of rating agencies as generating value, not by providing valuable information, but by enabling issuers and investors to satisfy certain regulatory requirements. Taking this perspective, he advocates eliminating regulatory dependence on credit ratings by substituting a regime based on market-determined bond credit spreads.

While the great moderation period dampened the intensity of this debate, the global crisis of 2008-9, and the euro crisis since 2010, again put to the fore concerns about the information content of ratings and the market impact of credit rating agencies. The heightened volatility and turbulence associated with the crises during the late 2000s provided new and rich information, propagating insightful research. Alsakka and Gwilym (2010a) analyzed lead-lag relationships in sovereign ratings across five agencies, and finds evidence of interdependence in rating actions. Upgrade (downgrade) probabilities are much higher, and downgrade (upgrade) probabilities are much lower for a sovereign issuer with a recent upgrade (downgrade) by another agency. S\&P tends to demonstrate the least dependence on other agencies, and Moody's tends to be the first mover in upgrades. Rating actions by Japanese agencies tend to lag those of the larger agencies, although there is some evidence that they lead Moody's downgrades. In a paper that focuses on emerging markets, Alsakka and Gwilym (2010b) find that split-rated sovereigns are prone to be upgraded (downgraded) by the agency from whom a lower (higher) rating exists. The harsher the split ratings between two agencies, the greater the effect on probabilities of future rating changes. Split ratings among Moody's, S\&P and Fitch are influential on their rating migrations. The rating 
dynamics of Capital Intelligence, Japan Credit Rating Agency and Japan Rating \& Investment Information are affected by their rating disagreements with the larger agencies. Only Moody's upgrade decisions are influenced by rating differentials with the smaller agencies.

Ismailescu and Kazemi (2010) studied the effect of sovereign credit rating change announcements on the CDS spreads of the event countries, and their spillover effects on other emerging economies' CDS premiums. They find that positive credit rating events have a greater impact on CDS markets in the two-day period surrounding the event, and are more likely to spill over to other emerging countries. CDS markets anticipate negative events, and previous changes in CDS premiums can be used to estimate the probability of a negative credit event. The transmission mechanisms for positive events are identified as common creditors as well as competition in trade markets. The foreign exchange market reaction to of credit ratings has been investigated by Alsakka and Gwilym (2013). They found that rating agencies' signals do affect the own-country exchange rate and propagate spillover effects to other countries' exchange rates in the region. The impact of outlook and watch signals is stronger than the impact of actual rating changes. Market reactions and spillovers are far stronger during the financial crisis period, 20062010, than pre-crisis, 2000-2006. They also find differential effects of the various agencies. Negative news from all three major agencies has an impact, whereas only Moody's positive news produces a reaction. Negative news from Fitch tends to have the strongest effect.

The crisis of 2008-9 signalled the end of the great moderation, re-focused markets on sovereign risk and, perhaps, hitherto under-priced vulnerabilities. Arghyroua and Kontonikasb (2012) focused on the Euro sovereign debt crisis. They found a shift in market pricing behaviour. Prior to the global credit crunch (January 1999 - July 2007) they find that markets priced neither macro fundamentals nor the very low at the time international risk factor. Markets, however, apparently changed the pricing mode to one driven by macro-fundamentals and international risk during the crisis period. They also found evidence consistent with contagion, particularly among euro periphery countries. Unlike the early stages of the euro crisis, where contagion was mainly originating from Greece, the latter stages of the euro crisis involved multiple sources of contagion.

Aizenman et al. (2013), looking at the euro debt crisis in the context of the pricing of sovereign debt of 50 countries, concludes that some of these anomalies were specific to the 
pricing of the euro debt. They find a complex and time-varying environment, with a key role of fiscal space in pricing sovereign risk, controlling for other relevant macro variables. A structural break occurred during the turbulent 2008-10 crisis episode -- during the crisis, pricing of risk is largely decoupled fiscal space measures, and the TED spread (a proxy for market volatility) emerged as a key pricing factor in the crisis. The risk of default in the euro periphery countries group appeared to be somewhat "underpriced" relative to international norms in the period prior to the global financial crisis and substantially "overpriced" countries during and after the crisis, especially in 2010, with actual CDS values much higher than the model predicts given fundamentals. ${ }^{1}$ These results are also in line with Beirne and Fratzscher (2013), who showed that a deterioration in countries' fundamentals and a sharp rise in the sensitivity of financial markets to fundamentals were the main explanations for the rise in sovereign yield spreads and CDS spreads during the crisis, not only for euro area countries but globally. Yet, empirical models with economic fundamentals generally do a poor job in explaining sovereign risk in the pre-crisis period for European economies, suggesting that the market pricing of sovereign risk may not have been fully reflecting fundamentals prior to the crisis.

Against the background of this literature, we turn to evaluate the credit ratings and the pricing of sovereign debt during the Euro crisis.

\section{Data and Descriptive Statistics}

We use monthly data in our analysis ranging from January 2005 to August 2012 for the longest sample. Daily data on CDS prices taken from Markit ${ }^{2}$ is averaged into monthly values. The data are five-year on-the-run CDS spreads in USD on sovereign bonds. The quoting convention for CDSs is the annual premium payment as a percentage of the notional amount of the reference obligation. The sovereign CDS spreads are reported in basis points, with a basis

\footnotetext{
${ }^{1}$ A potential explanation for the switch from under- to over-pricing of default risk is that markets were forward looking, not pricing entirely on current fundamentals but on expected further deterioration in future fundamentals, especially in the realm of fiscal space. Alternatively, the results are consistent with multiple equilibrium with an abrupt switch from a "good" (optimistic) expectations equilibrium in the Euro Area - to a "bad" (pessimistic) expectations equilibrium in these same countries - with high expected default rates and high interest rates where fiscal positions are not sustainable.

${ }^{2}$ Markit receives contributed CDS data from market makers from their official books and records. According to the company, Markit "cleans" this data, testing it "...for stale, flat curves, outliers and inconsistent data." If a contribution fails any one of these tests, they discard it. Markit states that they ensure superior data quality for an accurate mark-to-market and market surveillance.
} 
point equals to $\$ 1,000$ to insure $\$ 10$ million of debt. ${ }^{3}$ The description, transformation and source for each of the variables used in the empirical analysis is given the data appendix.

Table 1 provides summary statistics on the CDS spreads for the European countries in our sample, showing country means, medians, standard deviations, minimum and maximum values and the number of observations. The countries in our sample include all of the twenty-seven European Union countries excepting Luxembourg. CDS data is not available for Luxembourg. Table 1 shows the wide divergence in CDS spreads across EU countries, with the low end of the spectrum (in terms of mean, median and standard deviations) represented by Finland and Germany and the high end of the spectrum represented by Greece and, to a much lesser extent, Cyprus and Portugal. ${ }^{4}$ Greece is the only country in the sample to have had a "credit event" (partial or full default) on March 9, 2012 that triggered CDS payments. ${ }^{5}$

Figure 1 shows the evolution of CDS spreads for four groups of countries: EU members, Euro Zone members, EU members that do not participate in the Euro Zone and the GIIPS (Greece, Italy, Ireland, Portugal and Spain). Average values for each group are shown in the figure. The GIIPS countries are dominating the sharp run-up in CDS spreads starting in 2010 for the EU and Euro Area. The average over the full 2005-12 sample for GIIPS was 310 basis points, while only 154 basis points for the Euro Area (83 for the Euro Area less GIIPS) and 134 basis points for the other EU (non-Euro Area). It is noteworthy that the non-Euro countries saw only modest increases over the sample period.

The credit ratings are taken from Standard and Poor's and Fitch. The alphabetic rating scales of the rating agencies together with our numerical rating transformation are given in Table 2. The high end of the rating scale of both Fitch and Standard and Poor's is AAA, and is given the numerical index of 25. Seven countries in the sample - Denmark, Finland, Germany, Luxembourg, Netherlands, Sweden and the U.K.- had the highest rating (AAA) from both credit

\footnotetext{
${ }^{3}$ For example, a spread of 197 basis points means that it costs 197,000 USD to insure against 10,000,000 in sovereign debt for 10 years; $1.97 \%$ of notional amount needs to be paid each year, so $0.0197 \times 10$ million $=$ $\$ 197,000$ per year.

${ }^{4}$ Interestingly, Finland has a lower average CDS spread and standard deviation than Germany. This may reflect the relatively stronger fiscal position of Finland, its successful resolution of a major banking crisis in the early 1990s and the perception that Germany may be politically pressured to provide particularly large amounts to fund EU-wide banking and fiscal bailouts.

${ }^{5}$ The International Swaps and Derivatives Association (ISDA), which determines whether a credit event has occurred, said the use of "collective action clauses (CACs) to amend the terms of Greek law governed bonds issued by The Hellenic Republic such that the right of all holders of the Affected Bonds to receive payments has been reduced." (Reported in Reuters, March 9, 2012).
} 
rating agencies for the entire sample period. The low end of the ratings spectrum is D for Fitch at a numerical rating of 1 . DD for Fitch and D for Standard and Poor's (their lowest rating) is numerical rated at 2. In our sample, however, the lowest rated country is Greece, which ranges from $\mathrm{A}+$ (numerical rating 21) for both credit rating agencies in January 2004 to CCC (numerical rating 8) in August 2012. The average rating for Greece over the sample period given by Fitch was 17.29 and given by Standard and Poor's was 16.67.

The rating levels as well as changes in ratings and dates are given in Table 3 . The ratings used in the empirical analysis are the average ratings between each of the two numerical scales for Standard Poor's and Fitch. Usually these ratings coincide but not always. For example, Ireland was rated BBB+ by Fitch and A by Standard and Poor's in December 2010, but both agencies rated Ireland $\mathrm{BBB}+$ in August 2012. Greece and Bulgaria had the lowest average ratings over the sample period. Greece had the largest number of downgrades during the sample period (8), followed by Portugal (5). Bulgaria has only one downgrade as its rating was amongst the lowest for the entire sample period. A number of countries had 4 downgrades over the sample period. Several countries also had upgrades, in some cases on two occasions (Estonia, Slovak Republic, Czech Republic, and Romania).

For illustrative purposes, Figure 2 shows the evolution of CDS spreads in Greece together with vertical lines showing the dates of credit rating downgrades. The Greek CDS data runs until the credit event announcement in March 2012. The announcement of CDS credit downgrades appear to significantly increase Greek CDS spreads. The very high level of CDS in February 2012 in Greece clearly indicated the high expectation of an imminent credit event that would result in CDS payments.

Figure 3 shows a scatter diagram of CDS spreads and credit ratings for the four groups of EU countries - total EU, Euro Zone, GIIPS and EU less Euro Zone. The average CDS spread and credit rating value for each country-month observation for the group is plotted in the figure. A clear negative relationship between the credit rating level and CDS spreads is evident. CDS spreads are much lower for highly rated sovereign bonds, indicating that market pricing is expecting less likelihood of default. The relationship is particular evident for the GIIPS and, to a lesser extent, for the Euro Area. This inverse relation is less strong for the non-Euro Area EU countries. A credit rating of 16 in the GIIPS group appears consistent with two CDS pricing 
equilibrium, 500 basis points and 2000 basis points. This is consistent with a "two equilibrium" interpretation of broader empirical results discussed below. (The Euro group follows a similar pattern, reflecting the pattern of the GIIPS members).

\section{Empirical Results}

This section presents our basic empirical results where we test the effect of changes in credit rating changes on changes in CDS spreads, controlling for a host of country-specific and global economic factors. We estimate panel regressions for 26 EU countries over January 2005August 2012 using monthly data. We estimate an equation of the form:

$$
\Delta C D S_{i t}=\beta_{0}+\beta_{1} \Delta \text { Credit Rating } \text { Rit }+\beta_{2}\left(Z_{i t}\right)+\mu_{i}+\varepsilon_{i t},
$$

where $\Delta$ Credit Rating $_{i t}$ is the change in the credit rating scale variable and $Z_{i t}$ is a vector of country specific and global control variables, $\mu_{i}$ indicates country fixed effects. We have pretested with a number of possible country-specific and global control variables including foreign exchange reserves, inflation, industrial production and unemployment. We report those that are consistently statistically significant. The main result linking change in credit ratings to change in CDS spreads is robust to every specification of the equation irrespective of the included control variables. We employ fixed effects panel estimation with clustered standard errors (clustered by country). Robust standard errors to control for heteroskedasticity and autocorrelation are reported.

We report the estimates from the baseline formulation of the model in Table 4. A one unit rise in the average credit rating ( $\Delta$ CreditRating) decreases CDS spreads within a very narrow range for all of the seven estimated equations, ranging from -43 to -47 basis points. All point estimates are significant at the 5 percent level of confidence. A one percent rise in the domestic stock price index lowers CDS spreads by -1.5 to -2.0 basis points. World commodity and oil price increases also consistently decrease CDS spreads, likely because world economic conditions are generally strong when these prices are rising. By contrast, a rise in the Vix index, reflecting global market uncertainty, generally increases domestic CDS spreads. The total observations range from 2350-2355 across model specifications and the R2 values range from $2 \%$ to $5 \%$. (Constant terms are included in the regressions but not reported for brevity). 
To get a sense of the relative economic significance of these variables we show the results of standardized variables in Table 5. Table 5 shows the previous results (Table 4) using standardized coefficients (where the data is normalized as unit standard deviations around the mean). The significance levels of the coefficients are not affected by this variable normalization. This procedure indicates that a one standard deviation rise in credit ratings lowers CDS spreads by -0.15 to -0.16 of a standard deviation, not dissimilar to the effect of a one standard deviation rise in equity prices $(-0.10$ to -0.15$)$. However, standardized changes in commodity prices, oil prices or the VIX, have effects of a small magnitude on CDS spreads. Clearly, credit rating changes have important statistical and economic effects on CDS spreads, even when controlling for a host of domestic and economic variables.

One issue that arises in this context is whether the response of market risk perceptions, as reflected in CDS spreads, to credit rating changes might be conditional upon the level of the credit rating. That is, do CDS spreads in countries with lower credit ratings respond more to credit rating downgrades than do spreads in countries with higher credit ratings? We test for these non-linear effects in Table 6. In these specifications we include an interaction term that multiplies the change in the credit rating by the credit rating level ( $\Delta$ CreditRating*RatingLevel). Combining the two coefficients and the level of credit ratings therefore allows us to test and measure whether the CDS response changes systematically with the level of the credit rating at the time of the downgrade (or upgrade). The specific functional form is given by:

$$
\begin{aligned}
\Delta C D S_{i t}= & \beta_{0}+\beta_{1} \Delta \text { CreditRating }{ }_{i t}+\beta_{2}(\Delta \text { CreditRating } * \text { RatingLevel }) \\
& +\beta_{3}\left(Z_{i t}\right)+\mu_{i}+\varepsilon_{i t}
\end{aligned}
$$

The results reported in Table 6 are again statistically significant with the expected signs of the coefficients, and are robust and stable. In particular, the negative term (-283 to -289) on $\Delta$ Credit Rating indicates the fall in CDS spreads for a country with an initial credit rate of zero. The coefficient on $\Delta$ CreditRating*RatingLevel, ranging from 14.2 to 14.5 , is interpreted as the marginal effect on the response for a given level of initial credit. The higher the initial credit rating level, the less is the response of credit rating upgrades (downgrades). For example, our estimates (using specification 7) suggest that a rise in the credit rating of a country (e.g. Greece) from $\mathrm{CCC}(8)$ to $\mathrm{CCC}+(9)$ would result in a reduction in the CDS spread by -170 points (= $284.073+14.274 * 8$ ), while a rise in credit rating for a country (e.g. Romania) with an initial 
rating of BBB- (16) to BBB (17) would decrease CDS spreads by -56 points. Clearly, the CDS response of credit rating changes to initially lower rated credits are much stronger than higher rated credits. In addition, the significance levels, signs and magnitudes of all of the control variables in the regressions of Table 6 are virtually identical to Table 4, indicating a set of stable and robust results.

One issue that arises with the specification of our interaction term for the regressions in Table 6 is that the linear specification gives unrealistic estimates once the level of credit ratings reach 20 and beyond (using regression number seven of Table 6). At this point, very small estimated negative effects (the expected effect a priori) turn to positive estimated effects of a rating rise. To address this issue, we considered several non-linear functional response forms ${ }^{6}$, the most promising of which is the piecewise linear regression model using the "spline" functional form ${ }^{7}$. The spline function allows several step discrete changes in the response of CDS ratings to credit rating changes. In particular, the effect on CDS spreads from a one unit rise in credit ratings may generally be declining the higher is the level of the credit rating, but there may also be several distinct threshold points (knots) where the marginal changes shift.

Spline estimation requires selection of number of knots and the threshold points (placement of knots). As an initial starting point to begin the estimation we chose two knots since the country ratings are located mainly in three regions, namely As, Bs and $\mathrm{Cs}^{8}{ }^{8}$ In order to find optimal location of these knots, we follow a two-stage procedure. First, we regress rating changes on level of rating by arbitrarily choosing initial knots of rating cut-offs 19 (A- and above) and 10 (B- and above), which gives the following equation:

$$
\Delta C D S_{i t}=\beta_{0}+\beta_{1} \text { Rating }_{i t}+\beta_{2} d_{1}\left(\text { Rating }_{i t}-10\right)+\beta_{3} d_{2}\left(\text { Rating }_{i t}-19\right)+\varepsilon_{i t} \text {. }
$$

Second, using the initial parameters and knot values, we implement a non-linear optimization for spline placement. ${ }^{9}$ The non-linear estimation of the model is an iterative, grid

\footnotetext{
${ }^{6}$ We also considered $\Delta$ CreditRating squared to capture non-linear effects and different effects for each level of credit rating. These results are omitted for brevity but are available from the authors upon request.

${ }^{7}$ See Green (2012; pages 158-160) for an excellent discussion of this technique.

${ }^{8}$ We also extended the work to three knots. The third knot threshold was not statistically significant.

${ }^{9}$ We use $\mathrm{nl}$ command in Stata to implement nonlinear estimation. The nl estimation fits the non-linear function by least squares using the alternative iterative methods including gradient method, Newton and Marquardt method, etc. For further details on non-linear estimation implemented, see Davidson and McKinnon (2004, ch.6).
} 
search process, where the residuals sum of squares at each combination of parameter values are evaluated to determine the set of parameter values producing the lowest residual sum of squares.

$$
\begin{aligned}
\Delta C D S_{i t}= & \left\{\alpha_{0}\right\}+\left\{\alpha_{1}\right\} \text { Rating }_{i t}+\left\{\alpha_{2}\right\} \max \left(\text { Rating }_{i t}-\left\{k_{1}=x_{1}\right\}, 0\right) \\
& +\left\{\alpha_{3}\right\} \max \left(\text { Rating }_{i t}-\left\{k_{2}=x_{1}\right\}, 0\right)+\epsilon_{i t},
\end{aligned}
$$

where the initial values for each alpha are corresponding betas from first equation. For knot placement, we again start with initial values of 10 and 19 for $x_{1}$ and $x_{2}$. We have also tried different initial values for knot placement at both first and second equation. The estimation results from second model gives $\mathrm{k}_{1}=8.65$ (between $\mathrm{CCC}$ and $\mathrm{CCC}+$ ) and $\mathrm{k}_{2}=14.5$ (between $\mathrm{BB}$ and $\mathrm{BB}+$ ). Finally, using these two knot placements, we estimate the fixed effect model involving the interaction of rating changes and rating level that we call spline estimation in equation (5).

The spline function estimated and presented in the tables is given by:

$$
\begin{array}{rl}
\Delta \text { CDS }_{i t}= & \beta_{0}+\beta_{1} \Delta \text { CreditRating }_{i t}+\beta_{2} d_{1} \Delta \text { CreditRating }_{i t} *\left(\text { Rating }_{i t}-8.65\right) \\
& +\beta_{3} d_{2} \Delta \text { CreditRating } \\
i t & *\left(\text { Rating }_{i t}-14.5\right)+\beta_{4}\left(Z_{i t}\right)+\mu_{i}+\varepsilon_{i t},
\end{array}
$$

where $d_{1}=1$ if rating $>=8.65$, zero otherwise; and $d_{2}=1$ if rating $>=14.5$, zero otherwise.

We report the spline function form in Table 7 and graph the estimated responses for each credit level for the full period in Figures $4 \mathrm{a}$ and $4 \mathrm{~b}$.

Figure $4 \mathrm{a}$ indicates that the response to a credit rate change is very large at the lowest credit ratings in our sample, with an estimated CDS response of -153 basis points associated when a credit rating of CCC- (scale 7) is upgraded to CCC (scale 8). However, the CDS response becomes much less sensitive (less negative) at somewhat higher ratings, implausibly becoming slightly positive in the 9-11 basis point range, and then gradually increasing. The shift from large negative to slightly positive is probably due to the large role played by Greece at the low end of the spectrum, making the results fragile in this range. The relevant range of credit ratings, excluding the low end of the range only occupied by Greece during our sample period, is shown in Figure 4b. This figure shows insensitivity of response at a B+ rating (scale of 12), reaching at maximum negative point of around -40 basis points at a $\mathrm{BB}+$ credit rating (scale of 15) and 
gradually becoming less sensitive for higher credit ratings. A credit rating rise from AA- (22), for example, results in almost no change in CDS spread.

\section{Empirical Extensions and Robustness Checks}

This section considers four extensions and robustness checks on the basic model specifications. The first issue that we consider is potentially different responses over time, i.e. between the tranquil (2005-07) period and global crisis (2008-12) period. These results are reported in Table 8 for the baseline specification and the non-linear spline function estimates. The results from the pre-crisis and the global crisis for the simple baseline model are reported in columns 2 and 3, respectively. (To compare results, column 1 shows the full sample result reported above). While the global crisis results are virtually identical to the full sample results, reported in column 1 , the results are very different for the pre-crisis sample. In particular, a one notch credit rating decline is estimated to have increased CDS spreads by only 2.3 basis points during 2005-07, but by 42 basis points during 2008-12. (The estimate is 43 basis points over the full sample period).

Estimating the spline function model across the pre-crisis sample (column 5) and crisis sample (column 6) periods also gives strikingly different results for the responsiveness of CDS to credit rating changes. (And crisis period estimates very similar to the full period results.) The pre-crisis period shows a very intuitive pattern - a substantial rise in CDS spreads in response to a one notch downgrade for low end credits $(\mathrm{CCC}+)$, gradually decreasing (in absolute value) for higher rated credits, until hitting a fairly high credit rating. There appears virtually no sensitivity of CDS to credit rating changes when credit ratings are in the A- to AAA range during the precrisis period. ${ }^{10}$ The spline function estimates for the full (and crisis periods) also suggest a large impact of credit rating changes at the low end of the credit spectrum, and insensitivity at the high end of the spectrum (A- to AAA range). By contrast, the full and crisis periods show quite different patterns from the pre-crisis periods for the mid-level sovereign credits.

The second issue we address in this section is whether there are systematic differences in the response of CDS spreads to credit rating changes in particular country groupings. These

\footnotetext{
${ }^{10}$ The full spline model was not able to be estimated for the pre-crisis period due to the lack of low-level credits during this period, as seen in the estimated parameters of Table 8 , column 5 . In particular d $1 * \Delta$ Rating*(scale-10) was not able to be estimated jointly with $\mathrm{d} 2 * \Delta$ Rating*(scale-19) in the estimating equation.
} 
results are shown in Tables 9a and 9b. The EU (third column of Table 9a) panel estimates are the baseline results of our full sample reported in Table 4. The coefficient estimates on $\triangle$ CreditRating for the full sample, our empirical focus, for the Euro Area (Table 9a) and GIIPS group (Table 9b) indicate a somewhat larger response than the baseline, but of the same order of magnitude (ranging from -43.4 to -62.5 ) and also significant the 5\% level. By contrast, the ten countries not participating in the Euro area, but members of the EU (Bulgaria, Czech Republic, Denmark, Hungary, Latvia, Lithuania, Poland, Romania, Sweden, United Kingdom) shown in column Table 9a, do not have the same estimated response as the Euro Area countries-- the point estimate is negative but, at -12.63 , is not significantly different than zero. This indicates that the non-Euro EU group responded quite differently than the Euro Area countries to changes in credit ratings.

To delve further into the issues of regional sub-samples and sub-periods, we also report in these tables the regional breakdowns including and excluding the GIIPS group, with these groupings estimated over the three sample periods (full, pre-crisis, global crisis). Comparing the Tables 9a and 9b for the pre-crisis period, the EU (Euro group) estimates are very similar whether or not the GIIPS are included. The EU (Euro) coefficient estimate on the change in credit ratings in the pre-crisis period is -2.24 (-0.99) including GIIPS in the sample and -2.27 (0.86) excluding GIIPS from the sample. By contrast, including GIIPS gives much large effects for the crisis period and full period for both the EU and Euro Area.

These results indicate that two different pricing mechanisms were at work in the pre-crisis and crisis periods, at least for the mid- and low level sovereign-credits (insensitive results were found in both periods for the highest rated credits). This supports work by Aizenman et al. (2013) and De Grauwe and Ji (2013) and others and may support a "good" (pre-crisis) and "bad" (crisis) equilibrium interpretation of events. However, we interpret the sub-sample results cautiously due to limited observations of credit rating changes over some credit level ranges.

The third issue we address in this section is contagion. Several recent papers have addressed the issue of contagion using CDS spreads or sovereign yields (e.g. Beirne and Fratzscher, 2013). ${ }^{11} \mathrm{We}$ are concerned here, by contrast, with the transmission of changes in

\footnotetext{
${ }^{11}$ A number of studies have considered various aspects of contagion. For example, Mink and De Haan (2013) consider how Greece "news" during the crisis in 2010 transmitted to 48 banks in Greece and elsewhere in Europe. Beetsma et al. (2013) explore co-movements among interest spreads vis-à-vis Germany on European public debt and
} 
credit ratings in the GIIPS area with changes in CDS spreads in other areas outside of GIIPS. We measure GIIPS rating changes in two ways. The first method ("Aggregate GIIPS Rating Index") measures the sum of the GIIPS rating changes in a given month, e.g. in a given month, if three of the GIIPS countries are downgraded one notch, one GIIPS country is downgraded by two notches, and one country is not downgraded, then the indicator would register a five notch change. The second method ("Maximum GIIPS Rating Index") measures the maximum of the changes in GIIPS, e.g. if during a given month, one country was downgraded by two notches, and the others by one notch, then the indicator would register a two notch change.

The results are shown in Table 10. The results on the Euro Area (less GIIPS) are given in columns (1)-(2) for the aggregate method and (5)-(6) for the maximum method. Both methods give consistent results. There is initially evidence of contagion from GIIPS to the Euro Area, but this effect disappears when own-country credit rating changes are taken into account. By contrast, the GIIPS credit rating changes have a positive effect on the non-Euro EU area and his effect is statistically significant using the "maximum" method. That is, a rise (decline) in the credit rating in the GIIPS area is transmitted as a positive (negative) change in the CDS spread. For our sample of significant and frequent downgrades in GIIPS, these results suggest that CDS spreads in the non-Euro EU area have fallen in response. Non-Euro EU area sovereign debt may be seen as a substitute asset that increases in demand when the perceived risk of holding GIIPS area sovereign debt increases.

Finally, the issue of simultaneity bias may arise in the context of our empirical specification since both the change in credit ratings and the change in CDS spreads are entered contemporaneously for a given month. The correlation is evident between the two series but the relationship could be running causally from the change in credit rating to the change in CDS spread. To address this issue, we consider an fixed effects instrumental variables approach (FE IV) to estimating our baseline model (column 7 of Table 4), comparing the results with the FE least squares estimates, and applying the Hausman test of simultaneity bias. ${ }^{12}$ The results indicate that the coefficients on the change in credit ratings in the FE estimator and FE IV

spillovers in response to macroeconomic and financial news. They investigate both how "news" affected domestic interest spreads and how it was propagated to other countries during the recent crisis period, thereby distinguishing between the so-called GIIPS countries (Greece, Italy, Ireland, Portugal and Spain) and other European countries.

${ }^{12}$ See Greene (2003), section 5.5, for a detailed description of the Hausman specification test. 
specifications of the model are not systematically different. ${ }^{13}$ The Hausman test therefore suggests that our FE estimates are consistent (and unbiased) and more efficient than the IV estimator.

\section{Conclusion}

Our paper reveals a complex and time varying association between credit ratings and the pricing of sovereign debt during the Euro crisis. Changes in credit ratings are informative, significant economically, and robust to controlling for conventional economic fundamentals. However, the association between credit rating changes and spreads follows a complicated nonlinear pattern dependent on the level of the credit rating. Applying a non-linear "spline" regression, we find high sensitivity (large change in spreads for a given change in ratings) at the very low end of credit ratings and then a $U$ shape - ratings at the moderately low end and very high end of credit levels are fairly insensitive, while middle ratings are quite sensitive to credit rating changes.

We do not find contagion from GIIPS credit downgrades to CDS spreads in other Euro Area countries once own-country credit rating changes are taken into account. By contrast, the GIIPS credit rating downgrades seem to have a positive effect on the non-Euro EU: a rise decline in the credit rating in the GIIPS area is transmitted as a decline in the CDS spread of Non-Euro EU. This is consistent with the Non-Euro EU area sovereign debt deemed as a substitute asset that increases in demand when the perceived risk of holding GIIPS area sovereign debt increases.

The association between credit rating changes and CDS spreads to shift between the precrisis and crisis periods. European countries had quite similar CDS responses to credit rating changes during the pre-crisis period, but large differences emerged during the crisis period between the now highly-sensitive GIIPS group and other European country groupings (EU and Euro Area excluding GIIPS, and the non-EU area). The response is largest in magnitude at the lowest credit rating but these effects appear to emerge mainly during the crisis period when the risk of sovereign default rises and markets price risk more aggressively. The pricing mechanism differs in the pre-crisis and crisis periods for the mid- and low level sovereign-credits, opening a significant gap between market perceptions of default risk and that conveyed by the credit rating

\footnotetext{
${ }^{13}$ In particular, the chi-square statistic of the difference in the coefficients between the FE and FE IV is 1.86 with 1 degree of freedom, with a probability of 0.17 .
} 
agencies. These results are consistent with multiple equilibrium in market pricing of sovereign default risk and raises questions about the consistency between market perceptions of risk and assessments made by credit rating agencies.

\section{References}

Aizenman, J., Hutchison, H., and Jinjarak,Y. (2013), 'What is the Risk of European Sovereign Debt Defaults? Fiscal Space, CDS Spreads and Market Pricing of Risk' Journal of International Money and Finance, 34, 37-59.

Alsakka, R., and ap Gwilym, O. (2010a),'Split sovereign ratings and rating migrations in emerging economies', Emerging Markets Review 11, 79-97.

Alsakka, R., and ap Gwilym, O., (2010b), 'Leads and lags in sovereign credit ratings' Journal of Banking \& Finance "Leads and lags in sovereign credit ratings," Journal of Banking \& Finance, 34, 2614-2626.

Alsakka, R., and ap Gwilym, O., (2013), 'Rating agencies' signals during the European sovereign debt crisis: Market impact and spillovers', Journal of Economic Behavior \& Organization, 85, 144-162.

Arghyroua, M. G., Kontonikasb, A., (2012), 'The EMU sovereign-debt crisis: Fundamentals, expectations and contagion' J. of Int. Fin. Markets, Inst. and Money, 22, 658- 677.

Beetsma, R., Giuliodori,M., de Jong, F., and Widijanto, D., (2013), 'Spread the news: The impact of news on the European sovereign bond markets during the crisis', Journal of International Money and Finance, 34, 83-101.

Beirne, J., and Fratzscher, M., (2013), 'The pricing of sovereign risk and contagion during the European sovereign debt crisis', Journal of International Money and Finance, 34, 60-82.

Cantor, R., and Packer, F., (1994), 'The credit rating industry', FRBNY Quarterly Review, Fallsummer, 1-26.

Cantor, R., and Packer, F., (1997), 'Differences of opinion and selection bias in the credit rating industry', Journal of Banking \& Finance 21, 1395-1417.

Davidson, R., and MacKinnon, J. G., (2004). Econometric Theory and Methods. New York: Oxford University Press.

De Grauwea P. and Y. Ji (2013) 'Self-fulfilling crises in the Eurozone: An empirical test' Journal of International Money and Finance, 34, 15-36.

Greene, W. H., (2003) Econometric Analysis. Fifth Edition, Prentice Hall (New Jersey).

Ismailescu, I., and Kazemi, H., (2010), 'The reaction of emerging market credit default swap spreads to sovereign credit rating changes', Journal of Banking \& Finance, 34, 28612873.

Mink, M., and De Haan J. (2013), 'Contagion during the Greek sovereign debt crisis', Journal of International Money and Finance, 34, 102-113.

Partnoy, F., (1999), 'The Sikel and Ebert of Financial Markets? Two Thumbs down for the Credit Rating Agencies', Washington University Law Quarterly, 77 (3) pp 619 - 718. 
Table 1: Descriptive Statistics for Sovereign Credit Default Swap Spreads

\begin{tabular}{|c|c|c|c|c|c|c|}
\hline & Mean & Median & SD & Minimum & Maximum & $\mathrm{N}$ \\
\hline \multicolumn{7}{|l|}{ Euro Area } \\
\hline Austria & 57.82 & 53.23 & 62.50 & 1.61 & 205.09 & 92 \\
\hline Belgium & 76.32 & 34.03 & 91.48 & 2.05 & 326.52 & 92 \\
\hline Cyprus & 242.76 & 65.08 & 418.86 & 5.70 & 1577.84 & 91 \\
\hline Estonia & 122.37 & 94.87 & 149.45 & 3.93 & 686.72 & 92 \\
\hline Finland & 24.40 & 19.59 & 24.92 & 1.15 & 83.63 & 92 \\
\hline France & 50.17 & 23.22 & 62.26 & 1.52 & 211.76 & 92 \\
\hline Germany & 28.82 & 21.26 & 30.45 & 1.38 & 102.02 & 92 \\
\hline Greece & 812.25 & 52.76 & 2019.63 & 5.05 & 10633.20 & 86 \\
\hline Ireland & 220.77 & 102.63 & 276.82 & 1.88 & 986.28 & 92 \\
\hline Italy & 125.60 & 69.53 & 152.25 & 5.76 & 536.11 & 92 \\
\hline Malta & 111.38 & 71.95 & 127.27 & 4.86 & 417.17 & 91 \\
\hline Netherlands & 37.93 & 32.63 & 38.10 & 1.15 & 121.42 & 83 \\
\hline Portugal & 262.29 & 53.72 & 396.86 & 4.11 & 1323.36 & 92 \\
\hline Slovak Republic & 76.29 & 61.38 & 81.35 & 5.67 & 295.33 & 92 \\
\hline Slovenia & 86.67 & 55.55 & 119.74 & 3.57 & 475.97 & 92 \\
\hline Spain & 129.00 & 65.38 & 158.19 & 2.43 & 582.52 & 92 \\
\hline \multicolumn{7}{|c|}{ Other EU, Non-Euro } \\
\hline Bulgaria & 186.09 & 198.40 & 151.35 & 13.73 & 610.25 & 92 \\
\hline Czech Republic & 66.30 & 70.66 & 62.66 & 4.96 & 302.21 & 92 \\
\hline Denmark & 36.79 & 30.61 & 42.27 & 1.27 & 131.85 & 92 \\
\hline Hungary & 214.17 & 187.52 & 189.60 & 12.19 & 642.22 & 92 \\
\hline Latvia & 247.60 & 224.02 & 251.82 & 5.63 & 1038.80 & 92 \\
\hline Lithuania & 187.92 & 201.09 & 183.16 & 5.90 & 766.59 & 92 \\
\hline Poland & 104.16 & 99.48 & 91.17 & 7.98 & 362.81 & 92 \\
\hline Romania & 215.62 & 221.41 & 174.26 & 17.22 & 712.40 & 92 \\
\hline Sweden & 29.04 & 24.25 & 31.06 & 1.31 & 129.36 & 92 \\
\hline United Kingdom & 48.25 & 57.99 & 38.03 & 1.25 & 143.73 & 77 \\
\hline
\end{tabular}


Table 2: Linear Scaling of Credit Ratings

\begin{tabular}{lll}
\hline \hline Fitch Ratings & S\&P Ratings & Numerical Scale \\
\hline AAA & AAA & 25 \\
AA+ & AA+ & 24 \\
AA & AA & 23 \\
AA- & AA- & 22 \\
A+ & A+ & 21 \\
A & A & 20 \\
A- & A- & 19 \\
BBB+ & BBB+ & 18 \\
BBB & BBB & 17 \\
BBB- & BBB- & 16 \\
BB+ & BB+ & 15 \\
BB & BB & 14 \\
BB- & BB- & 13 \\
B+ & B+ & 12 \\
B & B & 11 \\
B- & B- & 10 \\
CCC+ & CCC+ & 9 \\
CCC & CCC & 8 \\
CCC- & CCC- & 7 \\
CC & CC & 6 \\
C & - & 5 \\
RD & R & 4 \\
DDD & SD & 3 \\
DD & D & 2 \\
D & & 1 \\
\hline
\end{tabular}

Source: Fitch and Standard and Poor's websites, and authors' calculations. 
Table 3: Average Sovereign Ratings, Downgrades and Upgrades

\begin{tabular}{|c|c|c|c|c|c|c|}
\hline & \multicolumn{2}{|c|}{ Average Ratings } & \multicolumn{2}{|c|}{ Number of Downgrades } & \multicolumn{2}{|c|}{ Number of Upgrades } \\
\hline & Fitch & S\&P & Fitch & S\&P & Fitch & S\&P \\
\hline Austria & 25.00 & 24.91 & - & 1 & - & - \\
\hline Belgium & 23.74 & 23.89 & 1 & 1 & 1 & - \\
\hline Cyprus & 20.75 & 19.68 & 4 & 6 & 1 & 1 \\
\hline Estonia & 19.76 & 20.17 & 2 & 1 & 2 & 2 \\
\hline Finland & 25.00 & 25.00 & - & - & - & - \\
\hline France & 25.00 & 24.91 & - & 1 & - & - \\
\hline Germany & 25.00 & 25.00 & - & - & - & - \\
\hline Greece & 17.29 & 16.67 & 8 & 8 & 1 & 1 \\
\hline Ireland & 22.88 & 22.98 & 4 & 6 & - & - \\
\hline Italy & 21.93 & 20.92 & 3 & 3 & - & - \\
\hline Luxembourg & 25.00 & 25.00 & - & - & - & - \\
\hline Malta & 20.67 & 19.91 & - & 1 & 1 & - \\
\hline Netherlands & 25.00 & 25.00 & - & - & - & - \\
\hline Portugal & 21.39 & 20.18 & 5 & 5 & - & - \\
\hline Slovak R. & 20.45 & 20.29 & - & 1 & 2 & 2 \\
\hline Slovenia & 22.49 & 22.61 & 3 & 3 & 1 & 1 \\
\hline Spain & 24.18 & 23.80 & 4 & 5 & - & - \\
\hline Bulgaria & 16.42 & 17.16 & 1 & 1 & 1 & 2 \\
\hline Czech R. & 20.51 & 19.92 & - & - & 2 & 2 \\
\hline Denmark & 25.00 & 25.00 & - & - & - & - \\
\hline Hungary & 17.30 & 17.13 & 4 & 4 & - & - \\
\hline Latvia & 17.08 & 16.70 & 4 & 5 & 1 & 2 \\
\hline Lithuania & 18.33 & 18.30 & 3 & 3 & 1 & 1 \\
\hline Poland & 18.74 & 18.72 & - & - & 1 & 1 \\
\hline Romania & 15.95 & 15.40 & 1 & 1 & 2 & 1 \\
\hline Sweden & 25.00 & 25.00 & - & - & - & - \\
\hline UK & 25.00 & 25.00 & - & - & - & - \\
\hline
\end{tabular}

Source: Fitch and Standard and Poor's websites, and authors' calculations. 
Table 4: CDS Spreads and Credit Ratings

\begin{tabular}{|c|c|c|c|c|c|c|c|}
\hline & (1) & (2) & (3) & (4) & (5) & (6) & (7) \\
\hline \multirow[t]{2}{*}{$\Delta$ Credit Rating } & $-46.87^{* *}$ & $-44.15^{\star *}$ & $-45.83^{* *}$ & $-44.32^{* *}$ & $-44.46^{* *}$ & $-44.49^{* *}$ & $-43.41^{* *}$ \\
\hline & (19.410 & $(19.04)$ & $(19.48)$ & (19.68) & (19.68) & (19.66) & $(19.35)$ \\
\hline \multirow[t]{2}{*}{$\Delta$ Stock Prices } & & $-1.96^{* * *}$ & & & & & $-1.44^{* * *}$ \\
\hline & & $(0.42)$ & & & & & $(0.38)$ \\
\hline \multirow[t]{2}{*}{$\Delta$ Commodity } & & & $-1.71^{* * *}$ & & $-1.34^{* * *}$ & & $-0.97^{* * *}$ \\
\hline & & & $(0.34)$ & & $(0.24)$ & & $(0.25)$ \\
\hline \multirow[t]{2}{*}{ VIX } & & & & $1.10^{\star * *}$ & $0.69^{* *}$ & $0.78^{* *}$ & 0.38 \\
\hline & & & & $(0.33)$ & $(0.28)$ & $(0.36)$ & $(0.26)$ \\
\hline \multirow[t]{2}{*}{$\Delta$ Oil Price } & & & & & & $-0.97^{\star * *}$ & \\
\hline & & & & & & $(0.18)$ & \\
\hline Observations & 2,355 & 2,350 & 2,355 & 2,355 & 2,355 & 2,355 & 2,350 \\
\hline R-squared & 0.02 & 0.04 & 0.04 & 0.03 & 0.04 & 0.04 & 0.05 \\
\hline
\end{tabular}

Notes: Equations estimated with country fixed effects, clustered and robustness standard errors. Dependent variables: change in CDS. ${ }^{* *} p<0.01,{ }^{* *} p<0.05,{ }^{*} p<0.1$.

Table 5: CDS Spreads and Credit Ratings: Standardized Coefficients

\begin{tabular}{lccccccc}
\hline \hline & $(1)$ & $(2)$ & $(3)$ & $(4)$ & $(5)$ & $(6)$ & $(7)$ \\
\hline$\Delta$ Credit Rating & $-0.16^{* *}$ & $-0.15^{* *}$ & $-0.16^{* *}$ & $-0.15^{* *}$ & $-0.15^{* *}$ & $-0.15^{* *}$ & $-0.15^{* *}$ \\
& $(0.07)$ & $(0.07)$ & $(0.07)$ & $(0.07)$ & $(0.07)$ & $(0.07)$ & $(0.07)$ \\
$\Delta$ Stock Prices & & $-0.15^{* * *}$ & & & & & $-0.11^{* * *}$ \\
& & $(0.03)$ & & & & & $(0.03)$ \\
$\Delta$ Commodity & & & $-0.12^{* * *}$ & & $-0.10^{* * *}$ & & $-0.07^{* * *}$ \\
& & & $(0.03)$ & & $(0.02)$ & & $(0.02)$ \\
VIX & & & $0.11^{* * *}$ & $0.07^{* *}$ & $0.08^{* *}$ & 0.04 \\
& & & & $(0.03)$ & $(0.03)$ & $(0.04)$ & $(0.03)$ \\
$\Delta$ Oil Price & & & & & & $-0.08^{* * *}$ & \\
& & & & & & $(0.02)$ & \\
Observations & 2,355 & 2,350 & 2,355 & 2,355 & 2,355 & 2,355 & 2,350 \\
R-squared & 0.02 & 0.04 & 0.04 & 0.03 & 0.04 & 0.04 & 0.05 \\
\hline
\end{tabular}

Notes: Equations estimated with country fixed effects, clustered and robustness standard errors. Dependent variables: change in CDS. ${ }^{* *} p<0.01,{ }^{* *} p<0.05,{ }^{*} p<0.1$. 
Table 6: CDS Spreads and Credit Ratings with Interaction Effects

\begin{tabular}{lccccccc}
\hline \hline & $(1)$ & $(2)$ & $(3)$ & $(4)$ & $(5)$ & $(6)$ & $(7)$ \\
\hline$\Delta$ Credit Rating & $-288.05^{*}$ & $-283.06^{*}$ & $-286.71^{*}$ & $-288.84^{*}$ & $-287.55^{*}$ & $-286.41^{*}$ & $-284.07^{*}$ \\
& $(157.46)$ & $(156.24)$ & $(158.67)$ & $(157.37)$ & $(158.32)$ & $(157.89)$ & $(157.09)$ \\
$\Delta$ Credit & & $14.16^{*}$ & $14.28^{*}$ & $14.51^{*}$ & $14.42^{*}$ & $14.35^{*}$ & $14.27^{*}$ \\
Rating RatingLevel & $14.30^{*}$ & $(8.29)$ & $(8.41)$ & $(8.34)$ & $(8.39)$ & $(8.37)$ & $(8.33)$ \\
& $(8.35)$ & $-1.92^{* * *}$ & & & & & $-1.37^{* * *}$ \\
$\Delta$ Stock Prices & & $(0.42)$ & & & & & $(0.35)$ \\
& & & $-1.71^{* * *}$ & & $-1.30^{* * *}$ & & $-0.94^{* * *}$ \\
$\Delta$ Commodity & & & $(0.35)$ & & $(0.25)$ & & $(0.25)$ \\
& & & & $1.16^{* * *}$ & $0.76^{* * *}$ & $0.87^{* *}$ & $0.47^{*}$ \\
VIX & & & & $(0.32)$ & $(0.27)$ & $(0.35)$ & $(0.24)$ \\
& & & & & & $-0.88^{* * *}$ & \\
$\Delta$ Oil Price & & & & & & $0.18)$ & \\
Observations & 2,355 & 2,350 & 2,355 & 2,355 & 2,355 & 2,355 & 2,350 \\
R-squared & 0.07 & 0.09 & 0.09 & 0.08 & 0.09 & 0.09 & 0.10 \\
\hline
\end{tabular}

Notes: Equations estimated with country fixed effects, clustered and robustness standard errors. Dependent variables: change in CDS. ${ }^{* *} p<0.01,{ }^{* *} p<0.05,{ }^{*} p<0.1$ 
Table 7: CDS Spreads and Credit Ratings: Spline Function

\begin{tabular}{|c|c|c|c|c|c|c|c|}
\hline & (1) & $(2)$ & (3) & (4) & (5) & (6) & $(7)$ \\
\hline \multirow[t]{2}{*}{$\Delta$ Credit Rating } & $-997.91^{* * *}$ & $-989.00^{\star \star *}$ & $-1,007.82^{\star \star *}$ & $-995.39^{* * *}$ & $-1,004.11^{* * *}$ & $-998.96^{\star * *}$ & $-996.67^{* * *}$ \\
\hline & $(162.92)$ & $(162.41)$ & $(160.81)$ & $(166.46)$ & $(163.44)$ & (165.23) & (162.55) \\
\hline \multirow[t]{2}{*}{$\Delta$ Rating ${ }^{*}$ scale } & $120.36^{* * *}$ & $119.50^{* * *}$ & $121.87^{* * *}$ & $119.80^{* * *}$ & $121.20^{* \star *}$ & $120.37^{* * *}$ & $120.45^{\star * *}$ \\
\hline & $(23.78)$ & $(23.70)$ & $(23.51)$ & $(24.26)$ & $(23.85)$ & $(24.06)$ & $(23.73)$ \\
\hline \multirow[t]{2}{*}{$\begin{array}{l}\mathrm{d} 1^{*} \Delta \text { Rating }^{*} \text { (scale- } \\
8.65)\end{array}$} & $-136.20^{\star * *}$ & $-134.95^{\star * \star}$ & $-137.74^{* * *}$ & $-134.53^{* * *}$ & $-136.36^{\star * *}$ & $-134.97^{\star * *}$ & $-135.61^{* * *}$ \\
\hline & (33.19) & $(33.02)$ & $(32.81)$ & $(33.72)$ & $(33.19)$ & $(33.42)$ & $(33.01)$ \\
\hline \multirow{2}{*}{$\begin{array}{l}\mathrm{d} 2 * \Delta \text { Rating }{ }^{*} \text { (scale- } \\
14.49)\end{array}$} & $21.92^{*}$ & $21.22^{*}$ & $21.52^{*}$ & $20.60^{*}$ & $20.78^{*}$ & 19.90 & $20.69^{*}$ \\
\hline & $(12.32)$ & $(12.10)$ & $(12.04)$ & $(12.35)$ & $(12.12)$ & $(12.23)$ & (11.99) \\
\hline \multirow[t]{2}{*}{$\Delta$ Stock Prices } & & $-1.90^{\star * *}$ & & & & & $-1.32^{* * *}$ \\
\hline & & $(0.41)$ & & & & & $(0.34)$ \\
\hline \multirow[t]{2}{*}{$\Delta$ Commodity } & & & $-1.80^{\star * *}$ & & $-1.41^{* * *}$ & & $-1.07^{* * *}$ \\
\hline & & & $(0.34)$ & & $(0.25)$ & & $(0.25)$ \\
\hline \multirow[t]{2}{*}{ VIX } & & & & $1.16^{* * *}$ & $0.72^{* * *}$ & $0.83^{* *}$ & $0.44^{*}$ \\
\hline & & & & $(0.31)$ & $(0.26)$ & $(0.35)$ & $(0.24)$ \\
\hline \multirow[t]{2}{*}{$\Delta$ Oil Price } & & & & & & $-0.97^{* * *}$ & \\
\hline & & & & & & $(0.17)$ & \\
\hline Observations & 2,355 & 2,350 & 2,355 & 2,355 & 2,355 & 2,355 & 2,350 \\
\hline R-squared & 0.12 & 0.14 & 0.14 & 0.13 & 0.14 & 0.14 & 0.15 \\
\hline
\end{tabular}

Notes: Equations estimated with country fixed effects, clustered and robustness standard errors. Dependent variables: change in CDS. $\mathrm{d} 1=1$ if rating $>=8.65$, zero otherwise; $\mathrm{d} 2=1$ if rating $>=14.5$, zero otherwise. ${ }^{* *} p<0.01,{ }^{* *} p<0.05,{ }^{*} p<0.1$. 
Table 8: Functional Forms and Sub-Periods Results

\begin{tabular}{|c|c|c|c|c|c|c|}
\hline & \multicolumn{3}{|c|}{ Linear Functional Form } & \multicolumn{3}{|c|}{ Non-Linear Spline Function } \\
\hline & $\begin{array}{c}\text { Full Period } \\
2005-12 \\
\end{array}$ & $\begin{array}{c}\text { Pre-Crisis } \\
2005-07 \\
\end{array}$ & $\begin{array}{c}\text { Global Crisis } \\
2008-12 \\
\end{array}$ & $\begin{array}{c}\text { Full Period } \\
2005-12 \\
\end{array}$ & $\begin{array}{c}\text { Pre-Crisis } \\
2005-07\end{array}$ & $\begin{array}{c}\text { Global Crisis } \\
2008-12 \\
\end{array}$ \\
\hline & $(1)$ & $(2)$ & (3) & $(4)$ & $(5)$ & $(6)$ \\
\hline$\Delta$ Credit Rating & $\begin{array}{c}-43.40^{* *} \\
(19.35)\end{array}$ & $\begin{array}{c}-2.24^{\star \star \star} \\
(0.61)\end{array}$ & $\begin{array}{c}-41.96^{* *} \\
(21.10)\end{array}$ & $\begin{array}{c}-996.67^{* * *} \\
(162.55)\end{array}$ & $\begin{array}{c}-12.39^{* *} \\
(5.22)\end{array}$ & $\begin{array}{c}-984.99^{\star \star *} \\
(153.87)\end{array}$ \\
\hline$\Delta$ Rating ${ }^{*}$ scale & & & & $\begin{array}{c}120.45^{\star * *} \\
(23.73)\end{array}$ & $\begin{array}{l}0.52^{* *} \\
(0.25)\end{array}$ & $\begin{array}{c}122.12^{* * *} \\
(22.65)\end{array}$ \\
\hline $\mathrm{d} 1^{*} \Delta$ Rating ${ }^{*}$ (scale-8.65) & & & & $\begin{array}{c}-135.61^{* * *} \\
(33.01)\end{array}$ & & $\begin{array}{c}-140.88^{\star * *} \\
(32.20)\end{array}$ \\
\hline d2* $\Delta$ Rating ${ }^{*}$ (scale-14.5) & & & & $\begin{array}{l}20.69^{*} \\
(11.99)\end{array}$ & & $\begin{array}{l}23.16^{*} \\
(12.05)\end{array}$ \\
\hline$\Delta$ Stock Prices & $\begin{array}{c}-1.44^{* * *} \\
(0.38)\end{array}$ & $\begin{array}{c}0 \\
(0.02)\end{array}$ & $\begin{array}{c}-1.54^{\star * *} \\
(0.46)\end{array}$ & $\begin{array}{c}-1.32^{* * *} \\
(0.34)\end{array}$ & $\begin{array}{c}0 \\
(0.02)\end{array}$ & $\begin{array}{c}-1.39^{* * *} \\
(0.41)\end{array}$ \\
\hline$\Delta$ Commodity & $\begin{array}{c}-0.97^{* \star *} \\
(0.25)\end{array}$ & $\begin{array}{l}-0.02 \\
(0.01)\end{array}$ & $\begin{array}{c}-1.32^{* * *} \\
(0.40)\end{array}$ & $\begin{array}{c}-1.07^{\star \star \star} \\
(0.25)\end{array}$ & $\begin{array}{l}-0.02 \\
(0.01)\end{array}$ & $\begin{array}{c}-1.48^{* * *} \\
(0.40)\end{array}$ \\
\hline VIX & $\begin{array}{c}0.38 \\
(0.26)\end{array}$ & $\begin{array}{c}0.39^{* * *} \\
(0.06)\end{array}$ & $\begin{array}{c}0.3 \\
(0.34)\end{array}$ & $\begin{array}{l}0.44^{*} \\
(0.24)\end{array}$ & $\begin{array}{c}0.38^{* * *} \\
(0.06)\end{array}$ & $\begin{array}{c}0.34 \\
(0.30)\end{array}$ \\
\hline Observations & 2,350 & 900 & 1,450 & 2,350 & 900 & 1,450 \\
\hline R-squared & 0.05 & 0.19 & 0.05 & 0.15 & 0.20 & 0.14 \\
\hline
\end{tabular}

Notes: Equations estimated with country fixed effects, clustered and robustness standard errors. Dependent variables: change in CDS. $\mathrm{d} 1=1$ if rating $>=8.65$, zero otherwise; $\mathrm{d} 2=1$ if rating $>=14.5$, zero otherwise. ${ }^{* * *}$ $p<0.01,{ }^{* *} p<0.05,{ }^{*} p<0.1$. 
Table 9a: Regional Groups and Sub-samples: EU and Euro Area Including GIIPS

\begin{tabular}{|c|c|c|c|c|c|c|c|c|c|}
\hline & \multicolumn{3}{|c|}{ EU (including GIIPS) } & \multicolumn{3}{|c|}{ EURO (including GIIPS) } & \multicolumn{3}{|c|}{ Non-Euro } \\
\hline & $\begin{array}{c}\text { Pre- } \\
\text { Crisis: } \\
2005- \\
2007 \\
(1)\end{array}$ & $\begin{array}{c}\text { Global } \\
\text { Crisis: } \\
2008- \\
2012 \\
(2)\end{array}$ & $\begin{array}{c}\text { Full } \\
\text { Sample: } \\
2005- \\
2012 \\
(3)\end{array}$ & $\begin{array}{c}\text { Pre- } \\
\text { Crisis: } \\
2005- \\
2007 \\
(1)\end{array}$ & $\begin{array}{c}\text { Global } \\
\text { Crisis: } \\
2008- \\
2012 \\
(2)\end{array}$ & $\begin{array}{c}\text { Full } \\
\text { Sample: } \\
2005- \\
2012 \\
(3)\end{array}$ & $\begin{array}{c}\text { Pre- } \\
\text { Crisis: } \\
2005- \\
2007 \\
(1)\end{array}$ & $\begin{array}{c}\text { Global } \\
\text { Crisis: } \\
2008- \\
2012 \\
(2)\end{array}$ & $\begin{array}{c}\text { Full } \\
\text { Sample: } \\
2005- \\
2012 \\
(3)\end{array}$ \\
\hline$\Delta$ Credit Rating & $\begin{array}{c}-2.24^{* * *} \\
(0.61)\end{array}$ & $\begin{array}{c}-41.96^{\star *} \\
(21.10)\end{array}$ & $\begin{array}{c}-43.40^{* *} \\
(19.35)\end{array}$ & $\begin{array}{c}-0.99^{* * *} \\
(0.34)\end{array}$ & $\begin{array}{l}-44.76^{*} \\
(24.02)\end{array}$ & $\begin{array}{c}-50.00^{* *} \\
(23.14)\end{array}$ & $\begin{array}{c}-2.24^{* *} \\
(0.98)\end{array}$ & $\begin{array}{l}-17.34 \\
(16.17)\end{array}$ & $\begin{array}{c}-12.64 \\
(10.86)\end{array}$ \\
\hline$\Delta$ Stock Prices & $\begin{array}{c}0.00 \\
(0.02)\end{array}$ & $\begin{array}{c}-1.54^{\star * *} \\
(0.46)\end{array}$ & $\begin{array}{c}-1.44^{* * *} \\
(0.38)\end{array}$ & $\begin{array}{r}-0.010 \\
(0.02)\end{array}$ & $\begin{array}{c}-1.78^{* \star *} \\
(0.51)\end{array}$ & $\begin{array}{c}-1.70^{* * *} \\
(0.43)\end{array}$ & $\begin{array}{l}0.010 \\
(0.04)\end{array}$ & $\begin{array}{r}-1.180 \\
(0.75)\end{array}$ & $\begin{array}{l}-1.05^{*} \\
(0.60)\end{array}$ \\
\hline$\Delta$ Commodity & $\begin{array}{r}-0.020 \\
(0.01)\end{array}$ & $\begin{array}{c}-1.32^{* * *} \\
(0.40)\end{array}$ & $\begin{array}{c}-0.97^{* * *} \\
(0.25)\end{array}$ & $\begin{array}{l}0.010 \\
(0.01)\end{array}$ & $\begin{array}{c}-1.12^{* *} \\
(0.50)\end{array}$ & $\begin{array}{c}-0.79^{* * *} \\
(0.31)\end{array}$ & $\begin{array}{l}-0.06^{*} \\
(0.03)\end{array}$ & $\begin{array}{c}-1.63^{* * *} \\
(0.54)\end{array}$ & $\begin{array}{c}-1.33^{* * *} \\
(0.39)\end{array}$ \\
\hline Vix & $\begin{array}{c}0.39^{* * *} \\
(0.06)\end{array}$ & $\begin{array}{l}0.300 \\
(0.34)\end{array}$ & $\begin{array}{l}0.380 \\
(0.26)\end{array}$ & $\begin{array}{c}0.21^{* * *} \\
(0.04)\end{array}$ & $\begin{array}{l}0.140 \\
(0.48)\end{array}$ & $\begin{array}{l}0.390 \\
(0.37)\end{array}$ & $\begin{array}{c}0.67^{* * *} \\
(0.14)\end{array}$ & $\begin{array}{c}0.74^{\star * *} \\
(0.27)\end{array}$ & $\begin{array}{l}0.50^{* *} \\
(0.21)\end{array}$ \\
\hline Observations & 900 & 1450 & 2350 & 562 & 890 & 1452 & 338 & 560 & 898 \\
\hline $\begin{array}{l}\text { R-squared } \\
\text { \# of Countries }\end{array}$ & $\begin{array}{c}0.190 \\
26\end{array}$ & $\begin{array}{c}0.050 \\
26\end{array}$ & $\begin{array}{c}0.050 \\
26\end{array}$ & $\begin{array}{c}0.210 \\
16\end{array}$ & $\begin{array}{c}0.030 \\
16\end{array}$ & $\begin{array}{c}0.040 \\
16\end{array}$ & $\begin{array}{c}0.260 \\
10\end{array}$ & $\begin{array}{c}0.300 \\
10\end{array}$ & $\begin{array}{c}0.250 \\
10\end{array}$ \\
\hline
\end{tabular}

Notes: Equations estimated with country fixed effects, clustered and robustness standard errors. Dependent variables: change in CDS. ${ }^{* *} p<0.01,{ }^{* *} p<0.05,{ }^{*} p<0.1$.

Table 9b: Regional Groups and Sub-samples: EU and Euro Area Excluding GIIPS

\begin{tabular}{lccc|ccc|ccc}
\hline & \multicolumn{3}{c|}{ EU -- excluding GIIPS } & \multicolumn{2}{c|}{ EURO -- excluding GIIPS } & \multicolumn{3}{c}{ GIIPS } \\
\hline & Pre- & Global & Full & Pre- & Global & Full & Pre- & Global & Full \\
& Crisis: & Crisis: & Sample: & Crisis: & Crisis: & Sample: & Crisis: & Crisis: & Sample: \\
& $2005-$ & $2008-$ & $2005-$ & $2005-$ & $2008-$ & $2005-$ & $2005-$ & $2008-$ & $2005-$ \\
& 2007 & 2012 & 2012 & 2007 & 2012 & 2012 & 2007 & 2012 & 2012 \\
& $(1)$ & $(2)$ & $(3)$ & $(1)$ & $(2)$ & $(3)$ & $(1)$ & $(2)$ & $(3)$ \\
\hline$\Delta$ Credit Rating & $-2.27^{* * *}$ & $-25.11^{* *}$ & $-20.11^{* *}$ & $-0.86^{* *}$ & $-25.59^{*}$ & $-23.08^{*}$ & $-1.37^{*}$ & $-54.49^{*}$ & $-62.48^{* *}$ \\
& $(0.67)$ & $(10.88)$ & $(8.73)$ & $(0.35)$ & $(14.48)$ & $(12.84)$ & $(0.80)$ & $(31.77)$ & $(31.68)$ \\
$\Delta$ Stock Prices & 0.00 & $-1.01^{* *}$ & $-0.91^{* * *}$ & -0.020 & $-0.81^{* * *}$ & $-0.75^{* * *}$ & 0.030 & $-4.12^{* * *}$ & $-4.33^{* * *}$ \\
& $(0.02)$ & $(0.41)$ & $(0.32)$ & $(0.02)$ & $(0.30)$ & $(0.24)$ & $(0.03)$ & $(1.49)$ & $(1.35)$ \\
$\Delta$ Commodity & -0.020 & $-1.11^{* * *}$ & $-0.92^{* * *}$ & 0.010 & $-0.67^{* * *}$ & $-0.56^{* * *}$ & 0.020 & -2.170 & -1.330 \\
& $(0.02)$ & $(0.29)$ & $(0.20)$ & $(0.01)$ & $(0.21)$ & $(0.14)$ & $(0.01)$ & $(1.58)$ & $(0.97)$ \\
Vix & $0.42^{* * *}$ & $0.50^{* * *}$ & $0.34^{* * *}$ & $0.20^{* * *}$ & $0.32^{*}$ & $0.24^{*}$ & $0.26^{* * *}$ & -0.250 & 0.560 \\
& $(0.08)$ & $(0.16)$ & $(0.12)$ & $(0.06)$ & $(0.18)$ & $(0.12)$ & $(0.05)$ & $(1.54)$ & $(1.14)$ \\
Observations & 720 & 1176 & 1896 & 382 & 616 & 998 & 180 & 274 & 454 \\
R-squared & 0.200 & 0.240 & 0.210 & 0.170 & 0.190 & 0.180 & 0.360 & 0.040 & 0.050 \\
\# of Countries & 21 & 21 & 21 & 11 & 11 & 11 & 5 & 5 & 5 \\
\hline
\end{tabular}

Notes: Equations estimated with country fixed effects, clustered and robustness standard errors. Dependent variables: change in CDS. ${ }^{* * *} p<0.01,{ }^{* *} p<0.05,{ }^{*} p<0.1$. 
Table 10: Contagion - Effects of GIIPS Rating Changes on Euro and Non-Euro Countries

\begin{tabular}{lcc|cc|cc|cc}
\hline \hline & \multicolumn{3}{c|}{ Aggregate GIIPS Rating Index } & \multicolumn{4}{c}{ Maximum GIIPS Rating Index } \\
\cline { 2 - 9 } & \multicolumn{2}{c}{ Effect on Euro EU } & \multicolumn{2}{|c|}{ Effect on Non-Euro EU } & \multicolumn{2}{|c}{ Effect on Euro EU } & \multicolumn{2}{|c}{ Effect on Non-Euro EU } \\
& $(1)$ & $(2)$ & $(3)$ & $(4)$ & $(5)$ & $(6)$ & $(7)$ & $(8)$ \\
\hline$\Delta$ GIIPS Credit Rating & $-0.97^{* *}$ & -0.28 & 0.09 & 0.10 & $-1.67^{*}$ & -0.88 & $1.83^{* *}$ & $1.75^{* *}$ \\
& $(0.41)$ & $(0.51)$ & $(0.62)$ & $(0.61)$ & $(0.92)$ & $(0.87)$ & $(0.86)$ & $(0.85)$ \\
$\Delta$ Credit Rating & & $-22.71^{*}$ & & -12.64 & & $-22.54^{*}$ & & -12.41 \\
& & $(13.25)$ & & $(10.86)$ & & $(12.99)$ & & $(10.83)$ \\
$\Delta$ Stock Prices & $-0.81^{* * *}$ & $-0.75^{* * *}$ & $-1.05^{*}$ & $-1.04^{*}$ & $-0.80^{* * *}$ & $-0.74^{* * *}$ & $-1.04^{*}$ & $-1.03^{*}$ \\
& $(0.28)$ & $(0.24)$ & $(0.61)$ & $(0.61)$ & $(0.28)$ & $(0.24)$ & $(0.61)$ & $(0.61)$ \\
$\Delta$ Commodity & $-0.59^{* * *}$ & $-0.57^{* * *}$ & $-1.34^{* * *}$ & $-1.33^{* * *}$ & $-0.57^{* * *}$ & $-0.57^{* * *}$ & $-1.33^{* * *}$ & $-1.31^{* * *}$ \\
VIX & $(0.15)$ & $(0.15)$ & $(0.39)$ & $(0.39)$ & $(0.15)$ & $(0.14)$ & $(0.39)$ & $(0.39)$ \\
& $0.22^{*}$ & $0.24^{*}$ & $0.56^{* *}$ & $0.50^{* *}$ & $0.23^{*}$ & $0.24^{*}$ & $0.57^{* *}$ & $0.51^{* *}$ \\
Observations & $(0.13)$ & $(0.13)$ & $(0.23)$ & $(0.21)$ & $(0.12)$ & $(0.13)$ & $(0.23)$ & $(0.21)$ \\
R-squared & 998 & 998 & 898 & 898 & 998 & 998 & 898 & 898 \\
Number of Countries & 0.14 & 0.18 & 0.24 & 0.25 & 0.14 & 0.18 & 0.24 & 0.25 \\
\hline
\end{tabular}

Notes: Equations estimated with country fixed effects, clustered and robustness standard errors. Dependent variables: change in CDS. ${ }^{* * *} p<0.01,{ }^{* *} p<0.05,{ }^{*} p<0.1$ 
Figure 1: CDS Spreads: EU, Euro, Non-Euro (EU) and GIIPS

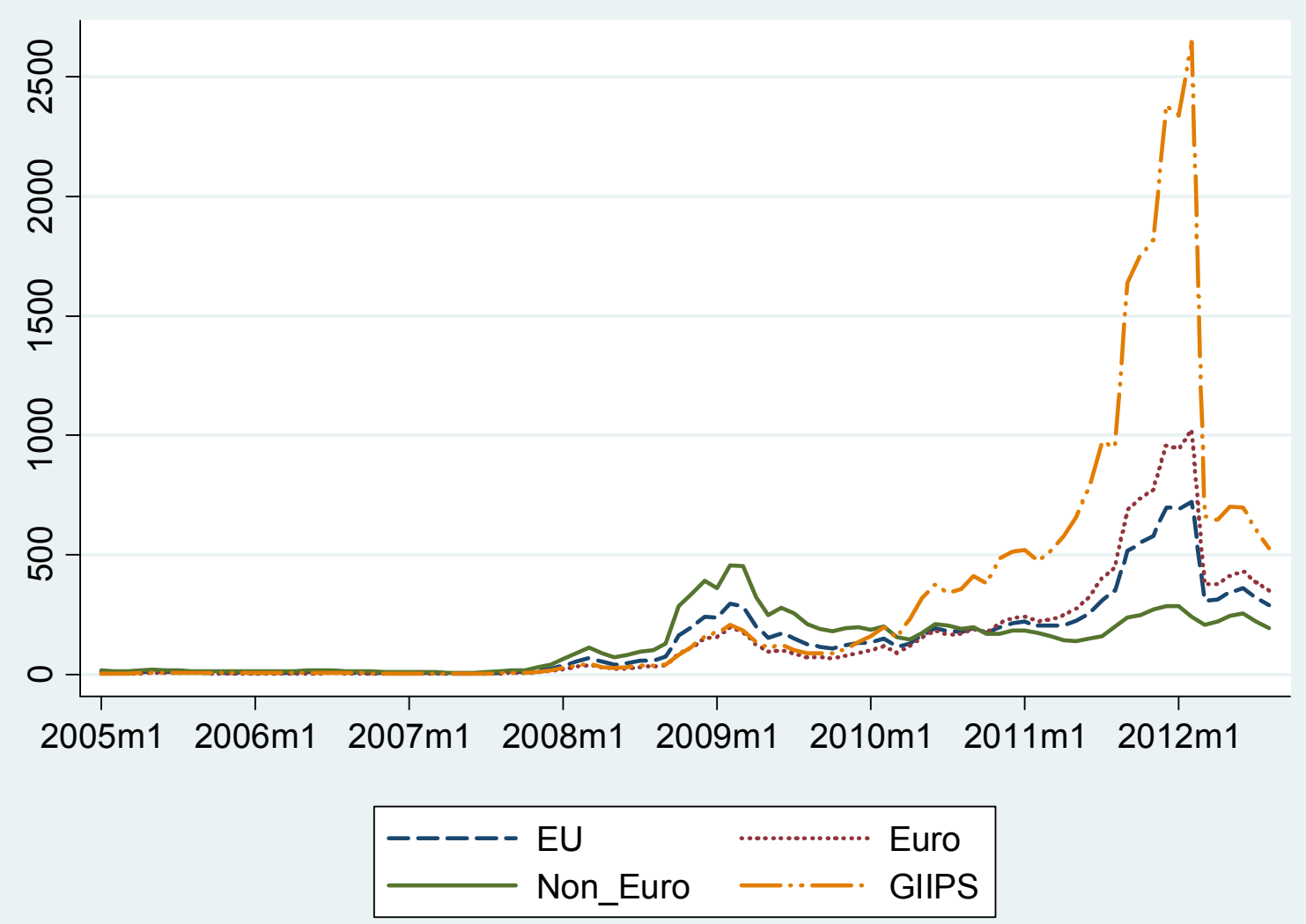

Notes: CDS spreads for Greece is not available after February 2012; therefore decline in average CDS is mainly due to Greek not being included in average. 
Figure 2: Greek CDS Spreads and Credit Rating Downgrades

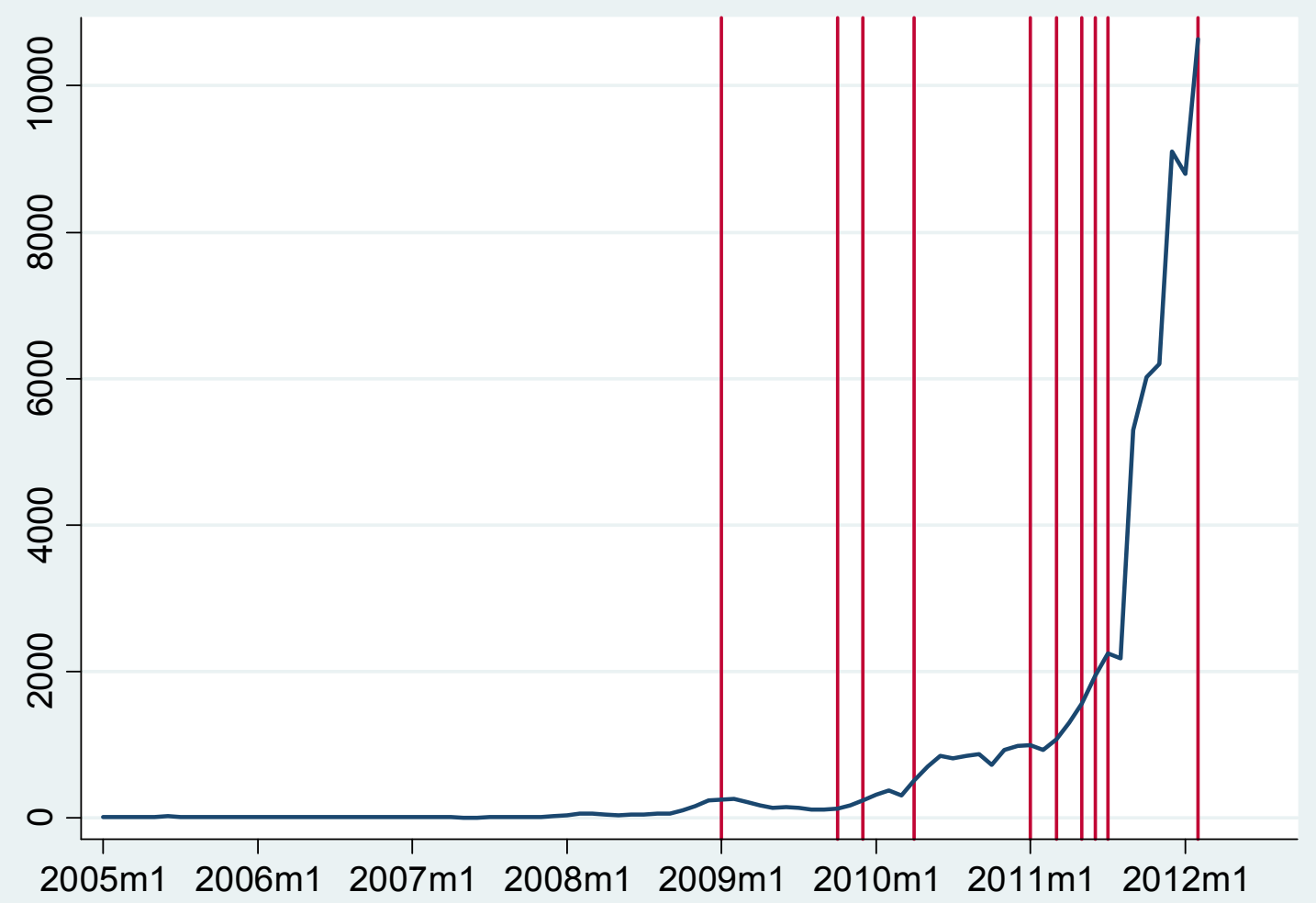

Notes: CDS spreads for Greece is not available after February 2012. Vertical lines indicate S\&P and Fitch dates of downgrades. 
Figure 3: CDS Spreads and Credit Ratings
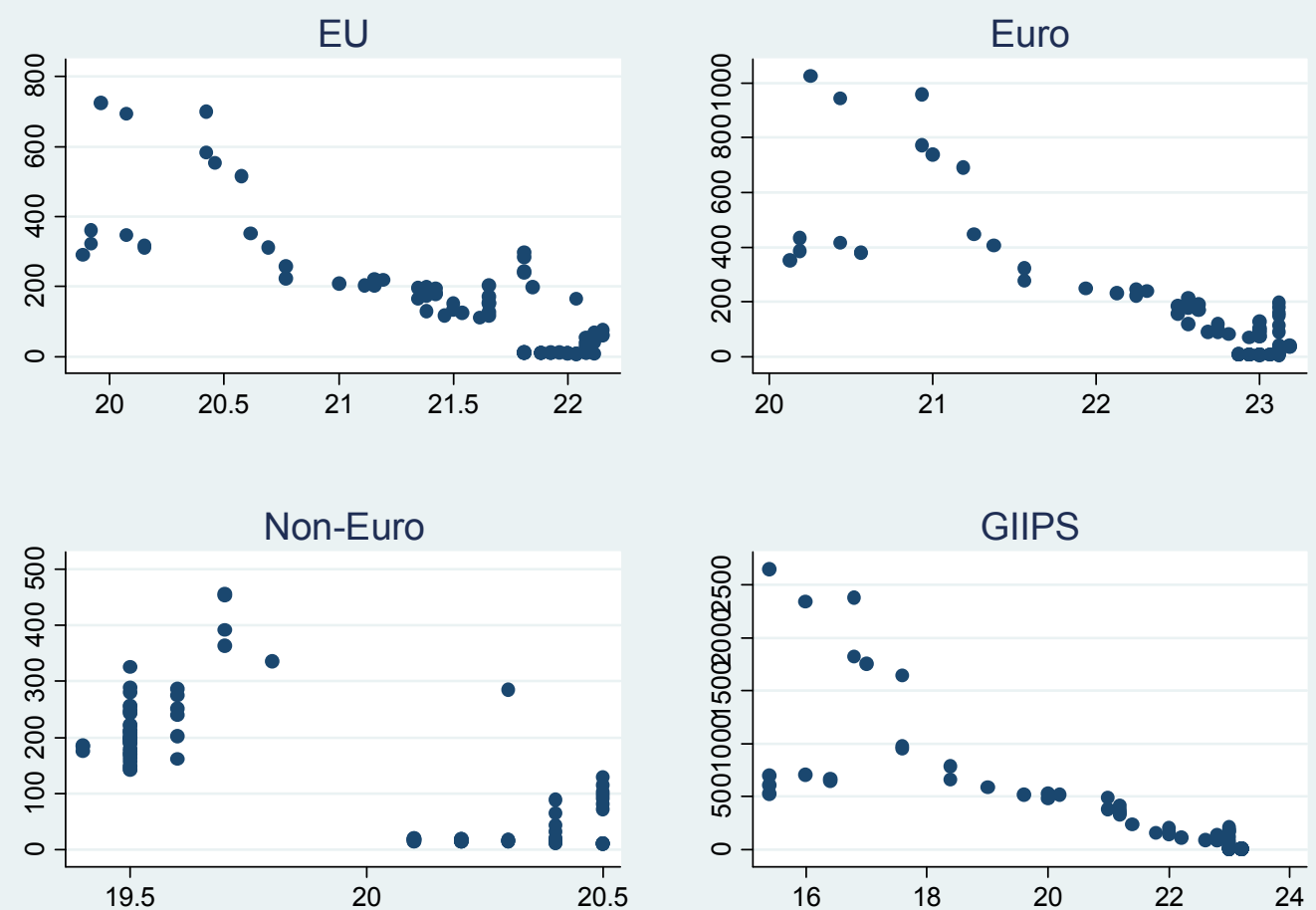

Notes: Vertical axis has CDS spreads; horizontal axis has sovereign ratings as scaled in Table 2. 
Figure 4a: Change in CDS Spread Associated with Credit Rating Change Conditional on Level of Credit Rating

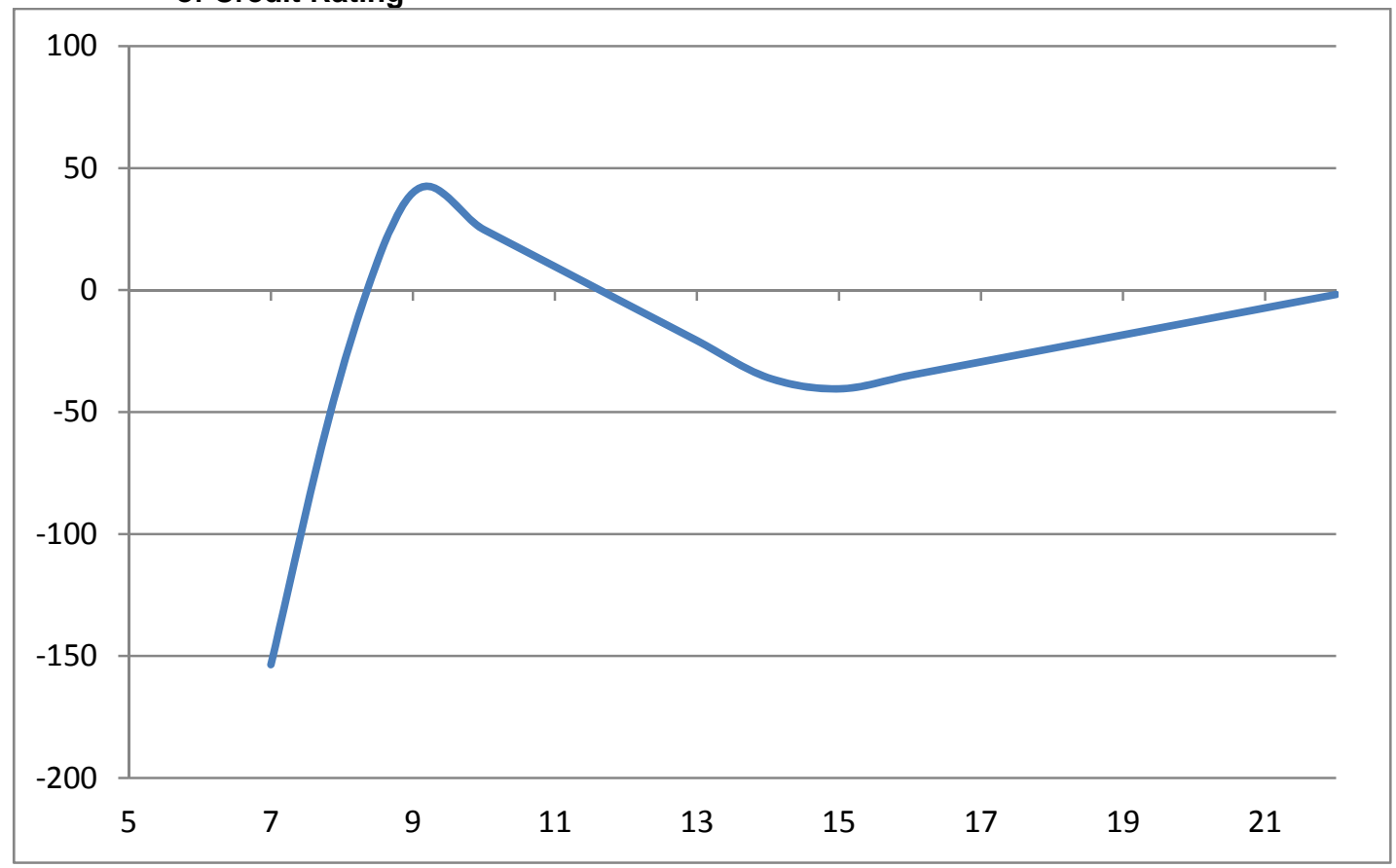

Notes: Full Sample (Pre-Crisis, Crisis) graph calculated from Table 7 (Table 8), Column 7 (Columns 5 , $6)$, spline function estimation. For credit rating level 19-25(A- to $A A A)$, $d 1=d 2=1$; for rating level 10-18 $(B-$ to $B B B+), d 1=1$ and $d 2=0$; for rating level $1-9(C C C+$ and below $), d 1=d 2=0$.

Figure 4b: Change in CDS Spread Associated with Credit Rating Change Conditional on Level of Credit Rating, excluding the low end of the range (only occupied by Greece during our sample period)

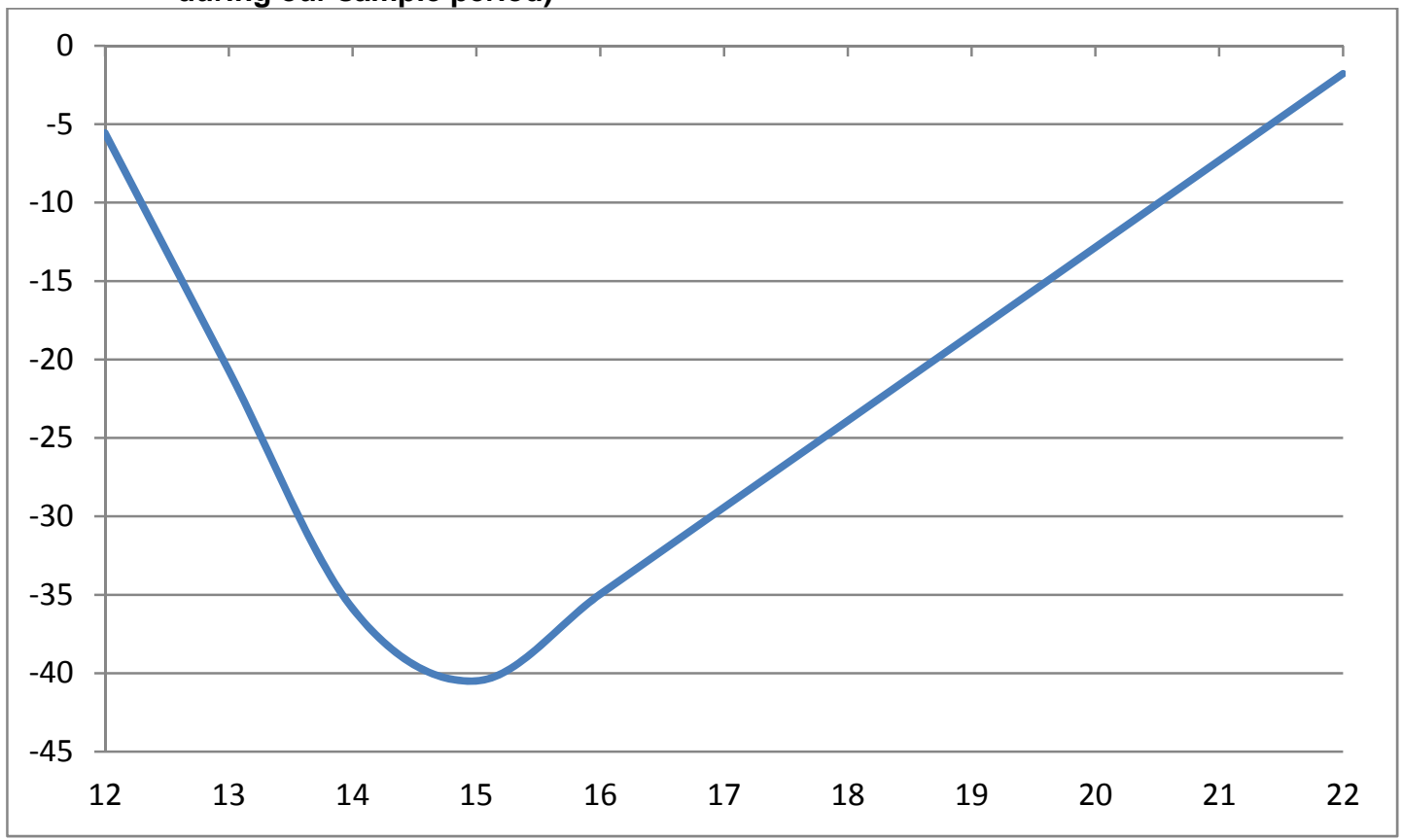

Notes: Full Sample (Pre-Crisis, Crisis) graph calculated from Table 7 (Table 8), Column 7 (Columns 5 , $6)$, spline function estimation. For credit rating level $19-25(A-$ to $A A A), d 1=d 2=1$; for rating level $10-18$ (B- to $B B B+), d 1=1$ and $d 2=0$; for rating level 1-9 $(C C C+$ and below $), d 1=d 2=0$. 
Table A1: Data Descriptions and Sources

\begin{tabular}{|c|c|c|}
\hline Variable & Description & Source \\
\hline CDS Spread & $\begin{array}{l}\text { Market prices for five-year sovereign CDS contracts (in a } \\
\text { basis points), daily data is averaged into monthly values. } \\
\text { Used as monthly basis point change in regressions. }\end{array}$ & Markit, Bloomberg \\
\hline Sovereign Ratings & $\begin{array}{l}\text { Fitch and Standard \& Poor's long-term foreign currency } \\
\text { ratings, scaled from } 1 \text { (D) to } 25 \text { (AAA). Monthly (in unit) } \\
\text { change }\end{array}$ & Fitch and S\&P websites \\
\hline Stock Prices & $\begin{array}{l}\text { Local Stock Market Index -- MSCI or host country. Used } \\
\text { as monthly percentage change in regressions. }\end{array}$ & $\begin{array}{l}\text { Bloomberg, Thomson } \\
\text { Reuters Datastream }\end{array}$ \\
\hline Commodity & $\begin{array}{l}\text { S\&P Goldman Sacks Commodity Price Index (SPGSCI), } \\
\text { US dollar. Used as monthly percentage change in } \\
\text { regressions. }\end{array}$ & Bloomberg \\
\hline Oil Price & $\begin{array}{l}\text { Crude oil price }(\$ / b b l) \text {, monthly average Used as monthly } \\
\text { percentage change in regressions. }\end{array}$ & $\begin{array}{l}\text { World Bank Commodity } \\
\text { Price Data (Pink Sheet) }\end{array}$ \\
\hline VIX & $\begin{array}{l}\text { Chicago Board Options Exchange Market Volatility Index } \\
\text { (implied volatility of S\&P } 500 \text { index options), monthly } \\
\text { average (of daily adjusted close) }\end{array}$ & Yahoo-Finance \\
\hline
\end{tabular}

